\title{
Studies on Insulin Secretion after the Administration of Sulfonylurea in Normal and Diabetic Subjects
}

\author{
Jun-ichiro OKAJIMA \\ The 1st Department of Internal Medicine, Kyoto Prefectural University of Medicine, Japan \\ (Director : Prof. H. Yoshida)
}

After the administration of sulfonylurea (glibenclamide and tolbutamide), insulin and blood glucose were estimated in the normal subjects and diabetics.

In the normal group glibenclamide $(5 \mathrm{mg})$ caused a tendency to decrease more markedly and maintain a lower level on blood glucose than tolbutamide (2.0g) after 120 minutes. While in the mild and moderate diabetic groups the blood glucose gradually lowered within 180 minutes after the administration of both glibenclamide and tolbutamide, although the lowering effect by glibenclamide was more remarkable in the moderate diabetic group. The increase of IRI secretion by glibenclamide was later in reaching a peak and then lasted longer than by tolbutamide in the normal group. In the diabetic groups, no significant increase of IRI was observed both by glibenclamide and tolbutamide. In the normal group glibenclamide caused a tendency to gradually elevate the plasma NEFA value for 180 minutes. On the contrary, in the moderate diabetic group it caused a tendency to continuously decrease during that time. These findings were also observed by the administration of tolbutamide. No qualitative difference between glibenclamide and tolbutamide was observed.

When a $50 \mathrm{~g}$ glucose load, preceded by the administration of glibenclamide, was carried out, the increases of insulinogenic index, half an hour after the glucose load, were significantly marked in the normal and mild diabetic groups, in comparison with the insulinogenic index on the glucose load only. A tendency to increase was also observed in the moderate diabetic group. While in the case of tolbutamide, that increase was significantly marked only in the normal group. Judging from these findings, it was suggested that the initial insulin secretion from $\beta$-cells to glucose load was increased by the previous administration of glibenclamide or tolbutamide.

It was assumed that the preprandial administration of glibenclamide was effective for the treatment of diabetes mellitus.

(See pp. 19〜29) 


\section{ズルファニール尿素剂投与時の糖尿病者 インシュリン分泌動態の研究}

京都府立医科大学第一内科学教室（指導: 吉田秀雄教授)

岡島純一 郎

(昭和48年 9 月17日受付)

Sulfonylurea 剤の糖尿病者に及ぼす作用及び治療効果について検討するため， tolbutamide（2.0g） 及び最近開発された glibenclamide $(5 \mathrm{mg})$ を糖尿病者に経口投与を行ない，その時の血糖 IRI，NEFA，GH を測定した。その結果従来の tolbutamide と glibenclamide の間には, その作用の強弱によ ると考元られる血糖降下の程度の差異を認めたが，質的な差は認めなかつた。

Glibenclamide 又は tolbutamide を経口投与し，60分後に50g GTT（それぞれ G-GTT, T-GTT と略す）を行ない，ブドウ糖負荷30分後の insulinogenic index (I.I と略す) を計算すると，G-GTT 時では正常者, 軽症糖尿病者群でそれぞれ単独 GTT 時のそれと比較して増加した。中等症糖尿病者 群でも G-GTT 時で I.I の増加する傾向がみられた. T-GTT では正常者群でのみ I.I の増加がみら れた。 これらの I.I の増加は, ブドウ糖負荷前に glibenclamide 及び tolbutamide を前投与すること により, ブドゥ糖負荷時の膵からの insulin の放出ないし分泌が六進されたと解され，言いかえれば， それらの薬剤の前投与が，膵 $\beta$-細胞のブドウ糖に対する感受性を増したものと考えられる。

てれらの事より Su 剂特に glibenclamide の食前投与は糖尿病治療に適すると推測される。

\section{緒 言}

1942年 Janbon ら ${ }^{1)}$ は sulfonamide 系化合物である P-aminosulfonamide isopropyl thiadiazole (IPTD) が血楉降下作用を有するととを報告し，1957年 Loubatieres 弓2) は IPTD の血糖降下作用は，膵 $\beta$ 細胞を 刺激してインシュリン分泌を增加する為であるとした．恩師吉田教授が日本内科学会宿題シンポジウムに於 て同様の結果を発表したのは翌年春のことである ${ }^{3)}$. 以来糖尿病の内服郕が開発され始め，今日抗糖尿病剤

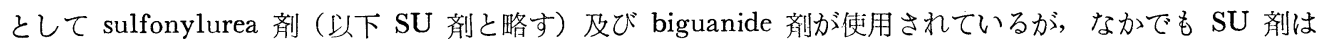
広く用いられている。

SU 剂については，特に tolbutamide そ関する治験成績が多い. 即ち, その効果は比較的一定しており, 副作用も少なく，Na 塩として静脈内投与も可能であるてと等の点で， SU 剤を代表するものとされてきた． 目下のとてろ SU 剂の作用機序は, 膵 $\beta$ 細胞作用して直接 insulin の放出ないし分泌を行なうことで, ほとんぞ一致した見解が得られている。 その根拠として, 膵を全剔した動物 ${ }^{4)}$ 又はヒト ${ }^{5)}$, 重症アロキサ ン糖尿病動物6) では血糖降下作用が認められないとと，また SU 剂投与後膵インシュリン量が減少し，血 中 insulin 様活性が増加する7) とと, 更に $\beta$ 細胞の脱顆粒現象が浔められ，ゴルジ装置は拡大する ${ }^{8) 9)}$ 等の 実験的事実に基いている.

一方糖尿病者においては, SU 剤投与後, 未梢血 IRI の増加がほとんど認められないにも拘らず, 投与 後血糖降下が持続的にわてるという事実も時には見られるので, SU 剤の作用機構として膵外作用が考劣ら れる。膵外作用については現在までの報告によると, 肝の insulinase の活性を阻害する ${ }^{10)}$ とか, 筋及び脂 肪組織に偅きブドウ糖摂取を促進する ${ }^{1112)}$ とか, 血清蛋白と結合した insulin を free form 亿変え, insulin 
を活性化する ${ }^{13)}$ 等の説明がなされているが，てれらについては現在でも一致した見解がみられていない.

さて最近開発された SU 剤の glibenclamide は tolbutamide に比べ微量で作用するてと, 本剤投与後の insulin 分泌 pattern が tolbutamide のそれと異なる ${ }^{14)}$ 点から，その作用機構は従来の SU 剂とは異質の ものであるという可能性が示唆されている，著者は両剤の作用機序について臨床的な立場から検討を加えた ので，その成績について述べる.

\section{実 験 対 象}

\section{1. 正常者群}

認めるべき疾患特に内分泌疾患及び代謝疾患がなく，遣伝的な糖尿病素因のない者を選んだ．

\section{2. 糖尿病者群}

$50 \mathrm{~g}$ 経ロブドウ糖負荷試験にわいて糖尿病型を示し，乙の様な異常を示す他原因が否定されて糖尿病と診 断されたもので，いわゆる成人発症型の者を選んだ。診断基準は日本糖尿病学会勧告值を用いた，更に本実 験に於ては, 糖尿病者の中で負荷前空腹時值が $120 \mathrm{mg} / \mathrm{dl}$ 以下のものを軽症糖尿病者, $130 \mathrm{mg} / \mathrm{dl}$ 以上で $280 \mathrm{mg} / \mathrm{dl}$ 以下のものを中等症糖尿病者とした.

以上，正常者群，糖㽷病者群とも，体重は標準体重の $\pm 20 \%$ 以内の者で年令は40〜60才までの者計 49 名に ついて以下の実験を行なつた。

\section{実 験 方 法}

試験前日の夕食後は絶食とし, 以下の各試験は当日の午前 9 時から施行した.

1) $50 \mathrm{~g}$ 経ロブドウ糖負荷試験 (GTT)

ブドゥ糖 $50 \mathrm{~g}$ を $300 \mathrm{ml}$ の水に溶かし，経口投与をおこなつた．投与直前，投与後 $30 ， 60 ， 90 ， 120 ， 180$ 分の計 6 回にわたり採血した。

2) Glibenclamide 又は tolbutamide 単独投与

glibenclamide $5 \mathrm{mg}$ 又は tolbutamide $2.0 \mathrm{~g}$ をそれぞれ粉末にして, 重曹 $2.0 \mathrm{~g}$ 及び少量の水と共に経口 投与し，投与前，投与後 $30 ， 60 ， 90 ， 120 ， 180$ 分の計 6 回にわたり採血した.

3） $50 \mathrm{~g}$ ブドウ糖負荷60分前に glibenclamide 又は tolbutamide を投与

GTT を行なう60分前に 2 ) と同様の方法で glibenclamide $5 \mathrm{mg}$ 又は tolbutamide $2.0 \mathrm{~g}$ 投与（以下それ ぞれ G-GTT, T-GTT と略す）し，ブドウ糖負荷前60分，30分，直前，ブドウ糖負荷後 $30 ， 60 ， 90 ， 120$ 分 の計 7 回にわたり採血した。

採血は肘静脈よりへパリン採血を行ない，血糖及び NEFA は採血後早急に測定したが，IRI，GH は測 定の都合上, 一度 $-20^{\circ} \mathrm{C}$ で涷結後一定数の検体を一度に測定した。

測定法は，血糖は Hagedron-Jensen 氏法を用い insulin 及び GH は Dainabot 社の insulin 及び成長 ホルモン測定 Kit による Radioimmunoassay 二抗体法 ${ }^{15)}$ で, NEFA は Duncombe 法 $^{16)}$ の変法である Itaya と Ui の方法 ${ }^{17)}$ につた.

\section{実 験 成 績}

\section{GTT (Table 1)}

a) 正常者群 ( I 群)

i ) 血糖: 空腹時值 $91 \pm 15($ mean \pm S.D $) \mathrm{mg} / \mathrm{dl}$ で糖負荷 30 分後 $144 \pm 16 \mathrm{mg} / \mathrm{dl}$ 亿達し， 1 時間値 $113 \pm$ $37 \mathrm{mg} / \mathrm{dl}, \quad 2$ 時間值 $87 \pm 23 \mathrm{mg} / \mathrm{dl}$ であつた.

ii ) IRI : 空腹時值 $20 \pm 7 \mu \mathrm{U} / \mathrm{ml}$ で負荷 30 分後 $78 \pm 23 \mu \mathrm{U} / \mathrm{ml}$ まで増加し, 60 分後 $63 \pm 22 \mu \mathrm{U} / \mathrm{m} 1,90$ 分 後 $46 \pm 11 \mu \mathrm{U} / \mathrm{ml}$ と漸次減少していつたが, 前值と比べいずれも有意 $(\mathrm{P}<0.01)$ 亿増加した.

b) 軽症糖尿病者群（II群） 
Table 1. Blood glucose and IRI on GTT in normal subjects and diabetics.

B.S : mg/dl, IRI : $\mu \mathrm{U} / \mathrm{ml}$

\begin{tabular}{|c|c|c|c|c|c|c|c|}
\hline & & $0^{\prime}$ & $30^{\prime}$ & $60^{\prime}$ & $90^{\prime}$ & $120^{\prime}$ & $180^{\prime}$ \\
\hline $\begin{array}{l}\text { normal } \\
\text { subjects } \\
(\mathrm{n}=8)\end{array}$ & $\begin{array}{l}\text { B.S } \\
\text { IRI }\end{array}$ & $\begin{array}{l}91.0 \pm 15.0 \\
20.3 \pm 6.5\end{array}$ & $\begin{array}{r}144.0 \pm 15.5 \\
77.9 \pm 22.8^{* *}\end{array}$ & $\begin{array}{r}112.5 \pm 36.9 \\
63.0 \pm 22.0^{* *}\end{array}$ & $\begin{array}{l}89.7 \pm 23.3 \\
46.1 \pm 11.1^{* *}\end{array}$ & $\begin{array}{l}87.0 \pm 16.1 \\
33.9 \pm 19.7\end{array}$ & $\begin{array}{l}72.9 \pm 15.7 \\
28.8 \pm 26.3\end{array}$ \\
\hline $\begin{array}{c}\text { mild } \\
\text { diabetics } \\
(\mathrm{n}=8)\end{array}$ & $\begin{array}{l}\text { B.S } \\
\text { IRI }\end{array}$ & $\begin{array}{r}102.9 \pm 12.3 \\
16.3 \pm 4.9\end{array}$ & $\begin{array}{l}91.0 \pm 25.6 \\
37.4 \pm 19.6^{*}\end{array}$ & $\begin{array}{c}242.1 \pm 42.0 \\
43.0 \pm 10.8^{* *}\end{array}$ & $\begin{array}{c}229.1 \pm 64.6 \\
44.3 \pm 25.2^{*}\end{array}$ & $\begin{array}{c}208.9 \pm 74.6 \\
34.1 \pm 14.6^{*}\end{array}$ & $\begin{array}{r}138.4 \pm 11.1 \\
20.1 \pm 11.1\end{array}$ \\
\hline $\begin{array}{l}\text { moderate } \\
\text { diabetics } \\
(\mathrm{n}=8)\end{array}$ & $\begin{array}{l}\text { B.S } \\
\text { IRI }\end{array}$ & $\begin{array}{r}176.0 \pm 36.6 \\
18.9 \pm 4.0\end{array}$ & $\begin{array}{c}262.0 \pm 45.2 \\
26.9 \pm 6.5^{*}\end{array}$ & $\begin{array}{r}311.5 \pm 78.6 \\
25.6 \pm 12.4\end{array}$ & $\begin{array}{c}345.5 \pm 76.2 \\
22.9 \pm 6.4\end{array}$ & $\begin{array}{c}301.1 \pm 67.1 \\
24.9 \pm 4.2^{*}\end{array}$ & $\begin{array}{c}232.0 \pm 73.6 \\
26.3 \pm 5.6^{*}\end{array}$ \\
\hline
\end{tabular}

i ）血糖：空腹時值は $103 \pm 12 \mathrm{mg} / \mathrm{dl}$ を示し，負荷 1 時間後最高值 $242 \pm 42 \mathrm{mg} / \mathrm{dl}$ に達し， 2 時間值 $209 \pm 75 \mathrm{mg} / \mathrm{dl}$ であつた.

ii） IRI : 空腹時值 $17 \pm 5 \mu \mathrm{U} / \mathrm{ml}$ で 30 分後 $37 \pm 20 \mu \mathrm{U} / \mathrm{ml}, 60$ 分後 $43 \pm 11 \mu \mathrm{U} / \mathrm{ml}, 90$ 分後 $44 \pm 25 \mu \mathrm{U} / \mathrm{ml}$ までいずれも有意に増加した後減少した。

c）中等症糖尿病者群（III群）

i ）血糖：空腹時值 $176 \pm 37 \mathrm{mg} / \mathrm{dl}$ で, 1 時間值 $312 \pm 79 \mathrm{mg} / \mathrm{dl}$ で，負荷 90 分後で最高值 $346 \pm 76 \mathrm{mg} / \mathrm{dl}$ まで上昇し， 2 時間值 $301 \pm 67 \mathrm{mg} / \mathrm{dl}$ を示した。

ii） IRI : 空腹時值 $19 \pm 4 \mu \mathrm{U} / \mathrm{ml}$ で 30分後 $27 \pm 7 \mu \mathrm{U} / \mathrm{ml}$ と有意（P<0.05） 亿増加した. 120分，180分 後でもそれぞれ有意（ $\mathrm{P}<0.05 ）$ そ増加した.

以上の如く血糖值についてみると，I，II， III群の順に，空腹時值， 1 時間值， 2 時間值が上昇している のは勿論であるが，最高值に達する迄の時間は，それぞれ 30分，60分，90分と順次遅延していた， IRI は 空腹時值では I， II， III群で有意の差はなく，ブドウ糖負荷後の早期の insulin 反応を表わすと考えられる 30分值では I 群に比べて II群，且群ではそれぞれ有意（P<0.01）に低值を示した．ブドウ糖負荷後30分の 血糖増加に対する IRI 増加の比即ち $\Delta \mathrm{IRI} / \Delta \mathrm{BS}$ も I 群では $1.23 \pm 0.60$, II 群 : 0.25 0.18, III群: 0.12 \pm 0.14 と I 群に比べてII, III群では有意（ $\mathrm{P}<0.01 ）$ そ低值であつた.

2. Glibenclamide 経口投与時の変化 (Table 2, 3)

a) 正常者群 ( I 群)

i ）血糖：空腹時值 $86 \pm 18$ (mean \pm S.D) $\mathrm{mg} / \mathrm{dl}$ で投与後，急激に下降し，60分後では $56 \pm 15 \mathrm{mg} / \mathrm{dl}$ と前值に比べ有意 $(\mathbf{P}<0.01)$ そ低下し, 以後 120 分後まではほとんど同じ值を示し, 以後前值に復する傾

Table 2. Blood glucose and IRI on glibenclamide test in normal subjects and diabetics

B.S : mg/dl, IRI : $\mu \mathrm{U} / \mathrm{ml}$

\begin{tabular}{|c|c|c|c|c|c|c|c|}
\hline & & $0^{\prime}$ & $30^{\prime}$ & $60^{\prime}$ & $90^{\prime}$ & $120^{\prime}$ & $180^{\prime}$ \\
\hline \multirow{2}{*}{$\begin{array}{l}\text { normal } \\
\text { subjects } \\
(\mathrm{n}=7)\end{array}$} & B.S & $86.3 \pm 17.6$ & $71.1 \pm 10.9$ & $55.9 \pm 14.9^{* *}$ & $55.4 \pm 15.5^{* *}$ & $54.6 \pm 10.3^{* *}$ & $58.7 \pm 15.1^{*}$ \\
\hline & IRI & $15.4 \pm 6.6$ & $30.7 \pm 19.7$ & $40.4 \pm 27.3^{*}$ & $29.7 \pm 25.0$ & $26.7 \pm 17.6$ & $27.3 \pm 17.5$ \\
\hline \multirow{2}{*}{$\begin{array}{c}\text { mild } \\
\text { diabetics } \\
(\mathrm{n}=8)\end{array}$} & B.S & $88.0 \pm 17.9$ & $80.1 \pm 17.3$ & $67.7 \pm 18.3$ & $59.9 \pm 17.8^{*}$ & $59.0 \pm 14.0^{* *}$ & $54.3 \pm 4.8^{* *}$ \\
\hline & IRI & $10.4 \pm 6.3$ & $15.0 \pm 5.8$ & $18.0 \pm 6.1$ & $15.9 \pm 6.6$ & $14.0 \pm 6.3$ & $11.6 \pm 4.2$ \\
\hline \multirow{2}{*}{$\begin{array}{c}\text { moderate } \\
\text { diabetics } \\
(\mathrm{n}=8)\end{array}$} & B.S & $186.3 \pm 41.6$ & $173.5 \pm 44.2$ & $162.5 \pm 51.9$ & $146.6 \pm 52.2$ & $116.4 \pm 24.8^{* *}$ & $113.8 \pm 47.6^{* *}$ \\
\hline & IRI & $12.6 \pm 9.0$ & $17.4 \pm 10.4$ & $16.9 \pm 10.3$ & $19.3 \pm 7.8$ & $21.0 \pm 11.0$ & $14.5 \pm 5.2$ \\
\hline
\end{tabular}


Table 3. GH and NEFA on glibenclamide test in normal subjects and diabetics

$\mathrm{GH}: \mathrm{m} \mu \mathrm{g} / \mathrm{ml}$, NEFA $: \mu \mathrm{Eq} / \mathrm{L}$

\begin{tabular}{|c|c|c|c|c|c|c|c|}
\hline & & $0^{\prime}$ & $30^{\prime}$ & $60^{\prime}$ & $90^{\prime}$ & $120^{\prime}$ & $180^{\prime}$ \\
\hline \multirow{2}{*}{$\begin{array}{l}\text { normal } \\
\text { subjects } \\
(n=7)\end{array}$} & $\mathrm{GH}$ & $1.3 \pm 1.4$ & $1.4 \pm 2.6$ & $2.0 \pm 1.2$ & $8.9 \pm 7.3$ & $12.0 \pm 9.4$ & $7.0 \pm 6.8$ \\
\hline & NEFA & $420 \pm 188$ & $455 \pm 141$ & $379 \pm 138$ & $442 \pm 148$ & $490 \pm 178$ & $510 \pm 216$ \\
\hline \multirow{2}{*}{$\begin{array}{c}\text { mild } \\
\text { diabetics } \\
(n=7)\end{array}$} & $\mathrm{GH}$ & $4.2 \pm 2.9$ & $1.7 \pm 0.5$ & $1.5 \pm 1.1$ & $4.1 \pm 5.5$ & $6.0 \pm 10.3$ & $4.8 \pm 4.6$ \\
\hline & NEFA & $577 \pm 203$ & $553 \pm 127$ & $438 \pm 100$ & $448 \pm 67$ & $517 \pm 105$ & $615 \pm 110$ \\
\hline \multirow{2}{*}{$\begin{array}{l}\text { moderate } \\
\text { diabetics } \\
(\mathrm{n}=8)\end{array}$} & $\mathrm{GH}$ & $1.6 \pm 0.7$ & $1.3 \pm 0.5$ & $3.1 \pm 2.9$ & $1.7 \pm 0.9$ & $1.7 \pm 2.9$ & $4.1 \pm 4.8$ \\
\hline & NEFA & $623 \pm 140$ & $654 \pm 121$ & $573 \pm 118$ & $527 \pm 95$ & $520 \pm 63$ & $532 \pm 145$ \\
\hline
\end{tabular}

向を示したが，180 分後においてもなお $59 \pm 15 \mathrm{mg} / \mathrm{dl}$ と有意（P<0.05） 亿低值を示した．個々の症例に つき投与後の各值を前值に対する\%として表わしたものが Fig. i であるが，投与後の最低值は前值の33〜84 \%と症例によりかなり差があつた。

ii） IRI : 空腹時值 $15 \pm 7 \mu \mathrm{U} / \mathrm{ml}$ を示し, 投与後 60 分で $40 \pm 27 \mu \mathrm{U} / \mathrm{ml}$ と前值に比べ有意 $(\mathrm{P}<0.05)$ そ 増加し, のち漸次減少した。

iii) $\mathrm{GH}$ : 空腹時值 $1.3 \pm 1.4 \mathrm{~m} \mu \mathrm{g} / \mathrm{ml}$ で90分後 $8.9 \pm 7.3 \mathrm{~m} \mu \mathrm{g} / \mathrm{ml}, 120$ 分後 $12 \pm 9.4 \mathrm{~m} \mu \mathrm{g} / \mathrm{ml}$ と有意 $(\mathrm{P}<$ 0.05）に上昇した。 1 例で頂值が $29.3 \mathrm{~m} \mu \mathrm{g} / \mathrm{ml}$ まで上昇したが，乙れは血糖值が前值の $33 \%$ まで低下した 症例であつた。

iv） NEFA：空腹時值 $420 \pm 188 \mu \mathrm{Eq} / \mathrm{L}$ を示し, 投与後平均值においては, 漸次上昇する傾向を示した。個 々の症例につき前值を 100 とした各時間の変動を示したのが Fig. 2 である.

b) 軽症糖尿病者群（II群）

i ）血糖：空腹時値 $88 \pm 18($ mean $\pm \mathrm{S} . \mathrm{D}) \mathrm{mg} / \mathrm{dl}$ で投与後 90 分で $60 \pm 18 \mathrm{mg} / \mathrm{dl}$ と前值に比し有意 $(\mathbf{P}<0.05)$ 飞低下し，120分，180分後でも有意（P<0.01）飞低下した.

Fig. 1. Effect of the oral administration of glibenclamide or tolbutamide on blood glucose

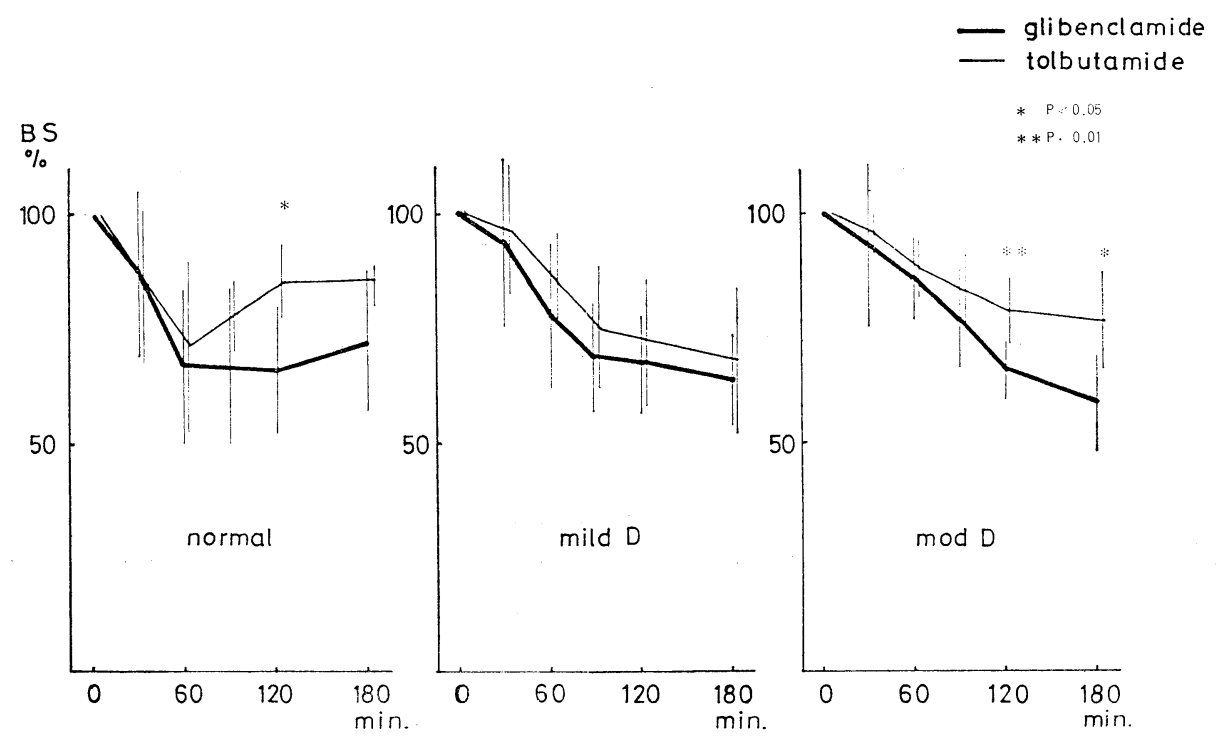


Fig. 2. Dynamicus in plasma NEFA after the oral administration of glibenclamide or tolbutamide

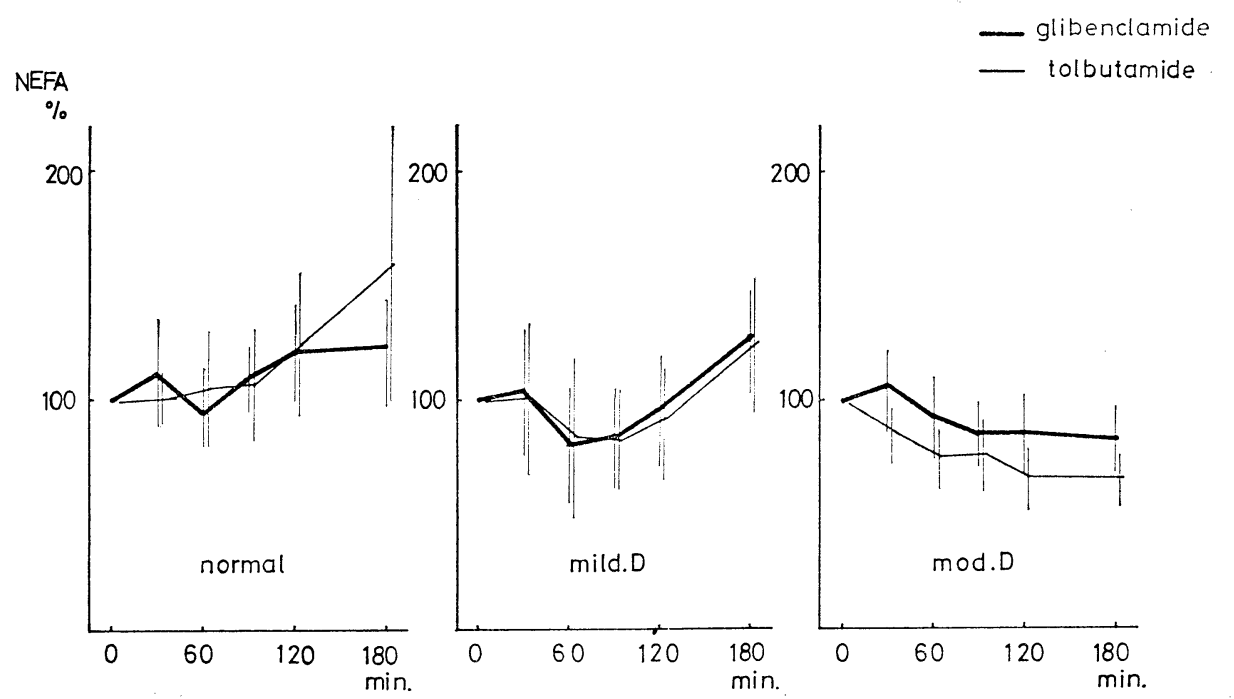

ii） IRI：空腹時 $10 \pm 6 \mu \mathrm{U} / \mathrm{ml}$ で， 60 分後 $18 \pm 6 \mu \mathrm{U} / \mathrm{ml}$ と平均值では増加する傾向を示したが，有意では なかつた。

iii) $\mathrm{GH}$ : 空腹時值 $4.2 \pm 2.9 \mathrm{~m} \mu \mathrm{g} / \mathrm{ml}$ で投与後有意な変化をみなかつた。

iv) NEFA : 空腹時值 $577 \pm 203 \mu \mathrm{Eq} / \mathrm{L}$ で, 投与後一旦下降し, のち上昇する傾向を示したが有意な変化 ではなかつた.

c）中等症糖尿病者群 (III群)

i ）血糖：空腹時值 $186 \pm 42($ mean \pm S.D $) \mathrm{mg} / \mathrm{dl}$ で投与後 180 分まで漸減する傾向を示し， 120 分後 $116 \pm 25 \mathrm{mg} / \mathrm{dl}, 180$ 分後 $114 \pm 48 \mathrm{mg} / \mathrm{dl}$ で前值に比し，それぞれ有意（P<0.01）に低下した.

ii ) IRI : 空腹時值 $13 \pm 9 \mu \mathrm{U} / \mathrm{ml}$ で投与後 120 分に $21 \pm 11 \mu \mathrm{U} / \mathrm{ml}$ と平均值では増加したが，有意ではな かつた.

iii） $\mathrm{GH}$ : 空腹時值 $1.6 \pm 0.7 \mathrm{~m} \mu \mathrm{g} / \mathrm{ml}$ を示し，投与後ほとんで変化しなかつた。

iv ) NEFA：空腹時值 $623 \pm 140 \mu \mathrm{Eq} / \mathrm{L}$ で投与後漸減する傾向を示したが有意な変化ではなかつた.

以上の様に glibenclamide 投与後, 血糖は I 群では早期に急激に下降し，その後前値に復する傾向をみ， 又II，III群になるに従い早期の血糖降下は軽度となり，投与後漸次低下し続ける傾向がみられたＩRIは投 与後 I 群では有意な増加をみ，II群では平均值では軽度増加したが有意でなく，III群でも有意の変化をみな かつた.

NEFA は I 群では投与後 180 分まで漸次上昇， II群では一旦下降後上昇， III群では漸次下降する傾向を みたが，それらの変化は空腹時値と比べ，有意ではなかつた，GH はI群で投与後 90 分で有意な増加をみ たが，IIIII群ではほとんで変動しなかつた。

3) Tolbutamide 投与時の変化 (Table 4,5)

a) 正常者群（I 群）

i ）血糖：空腹時值 $74 \pm 8($ mean \pm S.D $) \mathrm{mg} / \mathrm{dl}$ で，投与後急激に下降する傾向を示し，60分後には 52 $\pm 13 \mathrm{mg} / \mathrm{dl}$ まで有意（P<0.05）に下降し，後やや急激に前值に復する傾向を示したが，180分後でも62士 $6 \mathrm{mg} / \mathrm{dl}$ と有意 $(\mathrm{P}<0.05)$ 亿低值を示した.

ii ) IRI : 空腹時 $14 \pm 6 \mu \mathrm{U} / \mathrm{ml}$ で投与後 30 分值 $29 \pm 9 \mu \mathrm{U} / \mathrm{ml}$. 60分值 $20 \pm 2 \mu \mathrm{U} / \mathrm{ml}$ と前值と比べてそれ ぞれ有意（P<0.05）に増加したが，90分後には，ほとんど前值に復した. 
Table 4. Blood glucose and IRI on tolbutamide test in normal subjects and diabetics

BS : $\mathrm{mg} / \mathrm{dl}$, IRI $\mu \mathrm{U} / \mathrm{ml}$.

\begin{tabular}{|c|c|c|c|c|c|c|c|}
\hline & & $0^{\prime}$ & $30^{\prime}$ & $60^{\prime}$ & $90^{\prime}$ & $120^{\prime}$ & $180^{\prime}$ \\
\hline \multirow{2}{*}{$\begin{array}{l}\text { normal } \\
\text { subjects } \\
(n=6)\end{array}$} & B.S & $73.7 \pm 7.5$ & $64.7 \pm 10.4$ & $52.0 \pm 13.3^{*}$ & $57.3 \pm 6.0^{* *}$ & $62.2 \pm 3.8^{*}$ & $61.8 \pm 5.6^{*}$ \\
\hline & IRI & $13.8 \pm 6.0$ & $28.5 \pm 9.2^{*}$ & $20.2 \pm 2.1^{*}$ & $16.5 \pm 8.3$ & $16.2 \pm 4.8$ & $11.7 \pm 6.2$ \\
\hline \multirow{2}{*}{$\begin{array}{c}\text { mild } \\
\text { diabetics } \\
(\mathrm{n}=7)\end{array}$} & B.S & $99.0 \pm 12.9$ & $97.7 \pm 22.0$ & $85.7 \pm 17.3$ & $75.0 \pm 17.7^{*}$ & $70.7 \pm 16.9^{* *}$ & $67.6 \pm 21.3^{* *}$ \\
\hline & IRI & $9.1 \pm 6.2$ & $14.7 \pm 2.9$ & $14.4 \pm 8.6$ & $12.4 \pm 3.0$ & $11.6 \pm 5.4$ & $11.3 \pm 8.8$ \\
\hline \multirow{2}{*}{$\begin{array}{c}\text { moderate } \\
\text { diabetics } \\
(\mathrm{n}=7)\end{array}$} & B.S & $171.1 \pm 34.6$ & $163.9 \pm 30.6$ & $152.1 \pm 40.9$ & $144.7 \pm 41.6$ & $136.6 \pm 39.2$ & $134.4 \pm 48.7$ \\
\hline & IRI & $14.1 \pm 6.2$ & $16.9 \pm 7.0$ & $15.0 \pm 7.1$ & $18.9 \pm 7.4$ & $15.9 \pm 6.1$ & $17.0 \pm 5.6$ \\
\hline
\end{tabular}

Table 5. GH and NEFA on tolbutamide test in normal subjects and diabetics

$\mathrm{GH}: \mathrm{m} \mu \mathrm{g} / \mathrm{ml}, \mathrm{NEFA}: \mu \mathrm{Eq} / \mathrm{L}$

\begin{tabular}{|c|c|c|c|c|c|c|c|}
\hline & & $0^{\prime}$ & $30^{\prime}$ & $60^{\prime}$ & $90^{\prime}$ & $120^{\prime}$ & $180^{\prime}$ \\
\hline \multirow{2}{*}{$\begin{array}{c}\text { normal } \\
\text { subjecls } \\
(n=6)\end{array}$} & $\mathrm{GH}$ & $0.7 \pm 0.2$ & $0.6 \pm 0.4$ & $4.8 \pm 8.0$ & $8.3 \pm 9.4$ & $8.0 \pm 9.6$ & $4.4 \pm 4.6$ \\
\hline & NEFA & $317 \pm 102$ & $314 \pm 77$ & $317 \pm 51$ & $326 \pm 53$ & $365 \pm 65$ & $454 \pm 223$ \\
\hline \multirow{2}{*}{$\begin{array}{c}\text { mild } \\
\text { diabetics } \\
(n=6)\end{array}$} & $\mathrm{GH}$ & $2.9 \pm 2.9$ & $2.8 \pm 1.8$ & $4.3 \pm 5.0$ & $3.0 \pm 2.2$ & $3.1 \pm 2.1$ & $3.1 \pm 2.0$ \\
\hline & NEFA & $656 \pm 313$ & $595 \pm 187$ & $512 \pm 185$ & $548 \pm 183$ & $548 \pm 183$ & $717 \pm 133$ \\
\hline \multirow{2}{*}{$\begin{array}{c}\text { moderate } \\
\text { diabetics } \\
(\mathrm{n}=7)\end{array}$} & GH & $1.2 \pm 1.4$ & $1.1 \pm 0.9$ & $6.2 \pm 4.2$ & $2.1 \pm 2.4$ & $1.0 \pm 1.6$ & $1.4 \pm 1.4$ \\
\hline & NEFA & $623 \pm 184$ & $512 \pm 139$ & $458 \pm 99$ & $501 \pm 58$ & $396 \pm 96$ & $410 \pm 84$ \\
\hline
\end{tabular}

iii ) $\mathrm{GH}$ : 空腹時值 $0.7 \pm 0.2 \mathrm{~m} \mu \mathrm{g} / \mathrm{ml}$, 投与後 90 分で $8.3 \pm 9.4 \mathrm{mg} / \mathrm{dl}$ と平均值では増加したが, 前值に比 し有意でなかつた。

iv ） NEFA : 空腹時值 $317 \pm 102 \mu \mathrm{Eq} / \mathrm{L}$ で投与後漸次増加する傾向をみたが，前值と比べ有意でなかつた。

b) 軽症糖尿病者群（II 群）

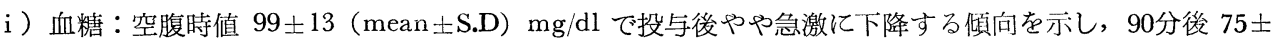
$18 \mathrm{mg} / \mathrm{dl}$ と前值に比べて有意（ $\mathrm{P}<0.05 ）$ 亿低下し，以後軽度ながら180分まで下降を続ける傾向を示した.

ii） IRI：空腹時値 $9 \pm 6 \mu \mathrm{U} / \mathrm{ml}$ で投与後 30 分で平均值 $15 \pm 3 \mu \mathrm{U} / \mathrm{ml}$ を示したが，有意な増加ではなか つた.

iii） $\mathrm{GH}$ : 空腹時值 $2.9 \pm 2.9 \mathrm{~m} \mu \mathrm{g} / \mathrm{ml}$ で投与後有意な変化はみられなかつた。

iv ） NEFA：空腹時値 $656 \pm 313 \mu \mathrm{Eq} / \mathrm{L}$ で投与後一旦下降し，のち上昇する傾向を示した.

c）中等症糖尿病者群（III群）

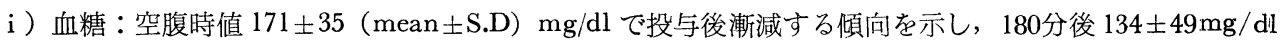
であつたが，前值に比し有意でなかつた。

ii ) IRI : 空腹時值 $14 \pm 6 \mu \mathrm{U} / \mathrm{ml}$ で投与後ほとんど変化しなかつた.

iii） $\mathrm{GH}$ : 空腹時值 $1.2 \pm 1.4 \mathrm{~m} \mu \mathrm{g} / \mathrm{ml}$ で投与後有意な変化をみなかつた。

iv ） NEFA : 空腹時值 $623 \pm 184 \mu \mathrm{Eq} / \mathrm{L}$ で投与後低下をつづける傾向があつたが有意な変化でなかつた.

以上の様に tolbutamide 投与時, 血糖は I 群では最も早期に低下した後前值に復する傾向がつよい。 II， III群では投与後溸次する傾向がみられた．IRI はI 群では投与30分及び60分後で有意の増加をみたがIII， III 群では有意でなかつた，空腹時 IRI 值は 3 群間で有意な差はなかつたが，投与30分後の insulin 值はI, II， III群でそれぞれ $29 \pm 9 \mu \mathrm{U} / \mathrm{ml}, 15 \pm 3 \mu \mathrm{U} / \mathrm{ml}, 17 \pm 7 \mu \mathrm{U} / \mathrm{ml}$ で， I 群と比べて II 群は有意 $(\mathrm{P}<0.01)$ に 
又亚群も有意（P<0.05）に低值を示した．NEFA はI 群では投与後180分まで連続的に増加，II群では初 期に低下し，のち上昇，衁群では連続的に 180 分まで低下する傾向をみたが, 有意な変化ではなかつた。

GH は I 群では90分後より上昇する傾向をみたが有意ではなく，II，姐群ではほとんど変化しなかつた．

[Glibenclamide 及び tolbutamide 投与時の変化の比較]

血糖值では，投与後の変動を各症例につき前值に対する\%として表わすと tolbutamide 投与時に比し， glibenclamide 投与時には，I群では120分後に有意（P<0.05）飞低值を示し， II群では 120 分，180分後 でそれぞれ有意（P<0.01 及び $\mathrm{P}<0.05 ）$ 亿低值を示した（Fig. 1) 他は IRI, GH NEFA 值は各群とも 両剤間に有意な差はなかつた。投与後の血糖, IRI, GH, NEFA の変動のパターンも各群とも両剤間で類 似していた。

4. $50 \mathrm{~g}$ ブドウ糖負荷60分前に Glibenclamide を投与した場合（ G-GTT) (Table 6)

a) 正常者群 ( I 群)

血糖は前值 $82 \pm 7($ mean $\pm \mathrm{S} . \mathrm{D}) \mathrm{mg} / \mathrm{dl}$ で Glibenclamide 投与60分後即ちブドウ糖負荷直前には $63 \pm 15$ $\mathrm{mg} / \mathrm{dl}$ でブドウ糖負荷 60 分で $103 \pm 30 \mathrm{mg} / \mathrm{dl}$ であつた.

IRI は空腹時值 $15 \pm 4 \mu \mathrm{U} / \mathrm{ml}$, ブドウ糖負荷直前 $28 \pm 14 \mu \mathrm{U} / \mathrm{ml}$, 負荷 30 分後に頂値 $81 \pm 22 \mu \mathrm{U} / \mathrm{ml}$ まで 增加した。

b) 軽症糖尿病者群（II 群）

空腹時血糖值 $100 \pm 10 \mathrm{mg} / \mathrm{dll}$ でブドウ糖負荷直前 $74 \pm 14 \mathrm{mg} / \mathrm{dl}$ を示し, ブドウ糖負荷 90 分後頂值 $146 \pm$ $24 \mathrm{mg} / \mathrm{dl}$ であつた.

IRI は空腹時值 $12 \pm 9 \mu \mathrm{U} / \mathrm{ml}$ であり, ブドウ糖負荷值前 $29 \pm 23 \mu \mathrm{U} / \mathrm{ml}$ であり, ブドウ糖負荷 60 分後, 90 分後でそれぞれ $58 \pm 33,58 \pm 19 \mu \mathrm{U} / \mathrm{ml}$ であつた。

c) 中等症糖尿病者群 (皿群)

空腹時血糖值 $163 \pm 36 \mathrm{mg} / \mathrm{dl}$ でブドウ糖負荷直前 $143 \pm 35 \mathrm{mg} / \mathrm{dl}$ でブドウ糖負荷90分後に頂值を示し， $234 \pm 51 \mathrm{mg} / \mathrm{dl}$ であつた.

IRI は空腹時值 $19 \pm 11 \mu \mathrm{U} / \mathrm{ml} ， フ ゙ ト ゙ ウ$ 糖負荷直前 $25 \pm 11 \mu \mathrm{U} / \mathrm{ml}$, ブドウ糖負荷 90 分後で $55 \pm 36 \mu \mathrm{U} / \mathrm{ml}$ を 示した.

Table 6. Blood glucose and IRI on GTT after glibenclamide administration in normal subjects and diabetics

B.S : mg/dl, IRI $: \mu \mathrm{U} / \mathrm{ml}$

\begin{tabular}{|c|c|c|c|c|c|c|c|c|}
\hline & & $-60^{\prime}$ & $-30^{\prime}$ & $0^{\prime}$ & $30^{\prime}$ & $60^{\prime}$ & $90^{\prime}$ & $120^{\prime}$ \\
\hline \multirow{2}{*}{$\begin{array}{l}\text { normal } \\
\text { subjects } \\
(n=7)\end{array}$} & B.S & $81.7 \pm 6.8$ & $62.9 \pm 9.5$ & $62.7 \pm 15.3$ & $90.1 \pm 16.5$ & $103.0 \pm 30.0$ & $66.4 \pm 13.7$ & $65.4 \pm 11.0$ \\
\hline & IRI & $15.3 \pm 4.2$ & $25.1 \pm 11.4$ & $28.0 \pm 14.4$ & $81.3 \pm 21.6$ & $68.7 \pm 21.3$ & $52.4 \pm 18.1$ & $46.7 \pm 30.3$ \\
\hline \multirow{2}{*}{$\begin{array}{c}\text { mild } \\
\text { diabetics } \\
(\mathrm{n}=7)\end{array}$} & B.S & $100.4 \pm 9.6$ & $95.6 \pm 11.5$ & $74.4 \pm 13.6$ & $104.0 \pm 7.9$ & $137.3 \pm 25.2$ & $145.6 \pm 24.1$ & $118.7 \pm 41.0$ \\
\hline & IRI & $12.1 \pm 9.2$ & $15.4 \pm 12.0$ & $28.7 \pm 22.5$ & $54.1 \pm 27.9$ & $58.3 \pm 33.0$ & $58.1 \pm 19.2$ & $54.1 \pm 24.7$ \\
\hline \multirow{2}{*}{$\begin{array}{c}\text { moderate } \\
\text { diabetics } \\
(\mathrm{n}=6)\end{array}$} & B.S & $163.0 \pm 35.8$ & $159.2 \pm 31.4$ & $142.8 \pm 34.5$ & $205.5 \pm 51.1$ & $231.8 \pm 47.6$ & $234.3 \pm 51.4$ & $209.2 \pm 53.4$ \\
\hline & IRI & $19.0 \pm 11.0$ & $23.8 \pm 12.1$ & $24.8 \pm 11.0$ & $48.3 \pm 21.2$ & $37.5 \pm 15.1$ & $54.7 \pm 35.6$ & $51.0 \pm 26.7$ \\
\hline
\end{tabular}

5. 50g ブドウ糖負荷60分前に tolbutamide を投与した場合（T-GTT) (Table 7)

a) 正常者群 ( I 群)

空腹時血糖值 $82 \pm 11 \mathrm{mg} / \mathrm{d} 1$ でブドウ 糖負荷直前 $66 \pm 13 \mathrm{mg} / \mathrm{dl}$ を示し，ブドウ糖負荷 60 分後に頂値 $100 \pm 17 \mathrm{mg} / \mathrm{dl}$ を示した.

IRI は空腹時值 $19 \pm 12 \mu \mathrm{U} / \mathrm{ml}$ でブドウ糖負荷直前 $22 \pm 12 \mu \mathrm{U} / \mathrm{ml}$ で, ブドウ糖負荷 30 分後に $83 \pm 26 \mu \mathrm{U} / \mathrm{ml}$ まで増加した。 
Table 7. Blood glucose and IRI on GTT ofter tolbutamide administration in normal subjects and diabetics

B.S : $\mathrm{mg} / \mathrm{dl}, \mathrm{IRI}: \mu \mathrm{U} / \mathrm{ml}$

\begin{tabular}{|c|c|c|c|c|c|c|c|c|}
\hline & & $-60^{\prime}$ & $-30^{\prime}$ & $0^{\prime}$ & $30^{\prime}$ & $60^{\prime}$ & $90^{\prime}$ & $120^{\prime}$ \\
\hline \multirow{2}{*}{$\begin{array}{l}\text { normal } \\
\text { suqjects } \\
(n=6)\end{array}$} & B.S & $82.4 \pm 11.3$ & $78.3 \pm 17.4$ & $66.3 \pm 13.2$ & $98.3 \pm 11.7$ & $99.8 \pm 16.6$ & $81.7 \pm 14.4$ & $87.8 \pm 10.0$ \\
\hline & IRI & $19.3 \pm 11.5$ & $36.3 \pm 10.6$ & $22.3 \pm 12.1$ & $83.0 \pm 25.8$ & $55.3 \pm 16.2$ & $41.2 \pm 10.2$ & $32.3 \pm 11.8$ \\
\hline \multirow{2}{*}{$\begin{array}{c}\text { milb } \\
\text { diabetics } \\
(\mathrm{n}=6)\end{array}$} & B.S & $92.2 \pm 19.5$ & $82.8 \pm 19.1$ & $71.0 \pm 14.8$ & $122.3 \pm 32.6$ & $149.8 \pm 34.6$ & $195.7 \pm 33.0$ & $165.5 \pm 32.4$ \\
\hline & IRI & $12.5 \pm 7.4$ & $20.3 \pm 6.7$ & $17.2 \pm 6.4$ & $29.2 \pm 8.0$ & $35.3 \pm 4.1$ & $49.5 \pm 21.0$ & $29.5 \pm 17.9$ \\
\hline \multirow{2}{*}{$\begin{array}{c}\text { moderate } \\
\text { diabetics } \\
(n=5)\end{array}$} & B.S & $189.4 \pm 46.7$ & $177.6 \pm 48.5$ & $171.6 \pm 45.4$ & $250.0 \pm 55.9$ & $307.6 \pm 65.6$ & $326.6 \pm 43.7$ & $289.6 \pm 33.9$ \\
\hline & IRI & $22.8 \pm 5.5$ & $29.4 \pm 4.8$ & $24.8 \pm 6.4$ & $35.6 \pm 14.1$ & $44.8 \pm 19.6$ & $49.2 \pm 20.2$ & $34.0 \pm 16.9$ \\
\hline
\end{tabular}

b）軽症糖疗病者群（II群）

空腹時血糖值は $92 \pm 20 \mathrm{mg} / \mathrm{dl}$ でブドウ糖負荷值前 $71 \pm 15 \mathrm{mg} / \mathrm{dl}$ でブドウ糖負荷 90 分後で頂值 $196 \pm 33$ $\mathrm{mg} / \mathrm{dl}$ であつた.

IRI は空腹時值 $13 \pm 7 \mu \mathrm{U} / \mathrm{ml}$ で，ブドウ糖負荷直前 $17 \pm 6 \mu \mathrm{U} / \mathrm{ml}$ を示し，ブドウ糖負荷 90 分後で $50 \pm 21$ $\mu \mathrm{U} / \mathrm{ml}$ まで増加した.

c）中等症糖尿病者群 (III群)

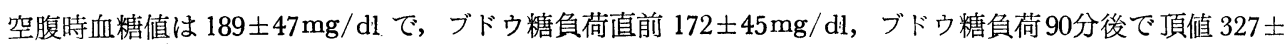
$44 \mathrm{mg} / \mathrm{dl}$ まで上昇した.

IRI は空腹時值 $23 \pm 6 \mu \mathrm{U} / \mathrm{ml}$ でブドウ糖負荷直前 $25 \pm 7 \mu \mathrm{U} / \mathrm{ml}$ を示し，ブドウ糖負荷 90 分後に $49 \pm 20$ $\mu \mathrm{U} / \mathrm{ml}$ となつた.

以上の成績をもとに, GTT, G-GTT, 及び T-GTT 時におけるブドウ糖負荷30分後の insulinogenic index (I.I) を計算した. (Table 8) その絬果 I.I は正常者群で GTT 時と G-GTT 時を比較すると，それぞれ $1.23 \pm 0.60,2.02 \pm 0.47$ で G-GTT 诗で有意 $(\mathrm{P}<0.05)$ 亿高值を示した. 軽症糖尿病者群でも GTT 及び G-GTT 時の I.I はそれぞれ 0.25 $\pm 0.18 ， 0.90 \pm 0.45$ で G-GTT 時において有意 $(\mathrm{P}<0.05)$ に高值を 示した，中等症糖㽷病者群ではそれぞれ $0.12 \pm 0.14,0.44 \pm 0.34$ と，G-GTT 将において，有意ではなか つたが GTT 時より高值を示す傾向がみられた. 又 GTT 時と T-GTT 時の I.I を比較すると, 正常者群 でそれぞれ $1.23 \pm 0.60 ， 1.94 \pm 0.50$ で T-GTT で有意 $(\mathbf{P}<0.05)$ 亿高值を小したが，軽症，敉等症糖 㽷病者群では，それらの差は認められなかつた。

Talbe 8. Insulinogenic index half an hour after the glucose loads in normal subjects and diabetics in each cases.

\begin{tabular}{l|c|c|c}
\hline & GTT & G-GTT & T-GTT \\
\hline normal subjects & $1.23 \pm 0.60$ & $2.02 \pm 0.47^{*}$ & $1.94 \pm 0.50^{*}$ \\
mild diabetics & $0.25 \pm 0.18$ & $0.90 \pm 0.45^{*}$ & $0.29 \pm 0.15$ \\
mod. diabetics & $0.12 \pm 0.14$ & $0.44 \pm 0.34$ & $0.15 \pm 0.13$ \\
\hline
\end{tabular}

上記 I.I は G-GTT, 及び T-GTT の際には，ブドウ糖投与後の血糖值及び IRI 值は，前もつて投与し た glibenclamide 又は tolbutamide による血糖下降と IRI 上昇が合わせて表現されていると考えられる ので, 先に行つた glibenclamide 又は tolbutamide 単独投与時の血糖, IRI の変化を差引いてみだ. 計算 方法は 2，3 で示した glibenclamide 又は tolbutamide 投与時の血糖及び IRI の変化の差を G-GTT 及 
び T-GTT 時のブドウ糖負荷後の血糖及び IRI の変動の差から差引いて計算したＩ群 G-GTT 時を例に とると,

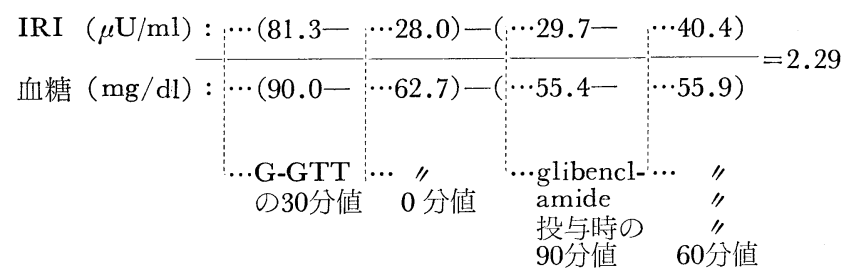

と計算した. (Table 9) その結果 G-GTT ではブドウ糖負荷30分後の I.I は, 単独 GTT 時のそれと比較 して正常者群, 糖尿病者群とも高值を示したが, T-GTT では正常者群のみ高值を示しており糖尿病者群で は殆んど不変であり, Table 8 にみられたのと同様の結果であり, 上記の影響を差引いても引かなくても同 結果であつた.

Table 9. Insulinogenic index half an hour after the glucose loads, in normal subjects and diabetics in each case when the blood glucose and IRI changes by the administration of glibenclamide or tolbutamide were deducted.

\begin{tabular}{l|c|c|c}
\hline & GTT & G-GTT & T-GTT \\
\hline \hline normal subjects & 1.09 & 2.29 & 2.43 \\
mild diabetics & 0.24 & 0.74 & 0.22 \\
mod. diabetics & 0.09 & 0.27 & 0.08 \\
\hline
\end{tabular}

考 按

Loubatieres $^{2)}$ らが IPTD の血糖降下作用が，膵 $\beta$-細胞を刺激してインスリンを分泌するととにあるとし て以来，SU 剂の作用機序について数多くの報告がある. 特に1959年 Berson \& Yalow ${ }^{18)}$ が Radioimmunoassay を開発して以来, insulin の測定が容易になり, 種々の条件下における SU 剂の insulin 分泌動態 が詳しく報告されている.

著者は SU 剤の作用を换討するため，糖尿病者に glibenclamide 及び tulbutamide を経口投与して検 討した結果，両剂間に一部その作用の強弱 ${ }^{19)}$ とよと考えられる血糖降下度に差をみたが，IRI，GH，NEFA 值は各群において両剂間に有意な差はなく, 投与後の血糖, IRI, GH, NEFA の変動 pattern も各群 において両剤間で類似しており本質的な差異は認めず，glibenclamide も従来の SU 剤と同一の作用をもつ ものと考えられる。しかし insulin 分泌 pattern が従来の SU 剂と異なる ${ }^{14)}$, 又 in vivo で血糖の変動を 認めずとも脂肪分解作用を示すとして質的に異なった作用をもつ可能性 ${ }^{20)}$ 示唆するものがある.しかし SU 剤投与後の末梢血 IRI 濃度及び insulin 分泌 pattern は投与量, 投与後の血中薬剤濃度の経時的な差 により影響され得るものであるし， insulin は糖代謝に及ぼす影響以上に脂肪分解作用が強力であり ${ }^{21) 22) ，}$ 従つて血糖の変動を示さない少量の insulin が脂肪分解抑制作用を示し得るものである.

糖尿病は insulin の相対的不足に基く代謝異常と考元られているが，Berson \& Yalow ${ }^{23)}$ は Radioimmunoassay を用いて, 糖㽷病者では $50 \mathrm{~g}$ 経口負荷後の insulin 反応が，負荷後早期において遅延反応を示すと とを見出した．Seltzer ${ }^{24)}$ らは静脈内ブドウ糖注入時でも同様の傾向を見出し，てれが糖尿病の根本的要因 と考え，ブドウ糖投与後の血糖上昇と血中 IRI 増加の比 $\Delta \mathrm{IRI} / \Delta \mathrm{BS}$ を insulinogenic index として表わす と糖尿病者では低下していると報告した。同様の成績は著者の成績でも $50 \mathrm{~g}$ GTT 時, 負荷後30分で認め られた。 
insulinogenic index は血糖上昇に対して, 膵 $\beta$-細胞が早期に如何に対処し得るかを示す指標と考えられ るが，長期には時間の経過と共に分泌された insulin が，血糖低下に働くことは当然であり，血糖上昇によ る insulin 分㦚を純粋にみることは難しくなると思われる。乙れらの事より著者は, 糖尿病状態の改善を 示す指標としてブドウ糖負荷 30 分後の I.I を測定し, 以下の検討をおてなつた.

臨床的立場より SU 剂の作用及び効果を研究する目的で, 食事捸取前に抗糖尿病薬を服用する日常の糖尿 病者の治療状況にかんがみ, $50 \mathrm{~g}$ ブドウ糖経口負荷60分前に glibenclamide 及び tolbutamide を経口投与 した。 その結果 glibenclamide 前投与時には, 正常者群, 軽症糖尿病者群とも, ブドウ糖投与後の I.I は ブドウ糖単独負荷時の I.I より有意 $(\mathrm{P}<0.05)$ 亿増加した. 中等症糖尿病者にわいても同様の傾向がみと められた. Tolbutamide 前投与時の場合は, 正常者群で, ブドウ糖単独負荷時より, I.I は有意 $(\mathbf{P}<0.05)$ に増加したが，糖尿病者群では増加しなかつた。乙れらの増加は $\mathrm{SU}$ 凨の前投与によりブドウ糖投与後早期 にみられる insulin 分泌が光進されたと理解される。言いかえれば glibenclamide 及び tolbutamide は膵 $\beta$-細胞から単に insulin を放出ないし分泌するのみならず，ブドウ糖負荷時に膵 $\beta$ 一細胞から insulin を より放出しやすい状況を準備するもので，ブドウ糖に対する苏 $\beta$ 一細胞の感受性を増す作用を有することを 示唆する。繁田 ${ }^{25)}$ らは Acetohexamide を前投与した時, ブドウ糖負荷時の insulin 分泌総量を測定し, 膵 $\beta$-細胞の感受性が増すととを示唆し, 著者と同様の所見を見出しており, Acetohexamide の有効判定に 利用し得るととを報告している. 又長期投与時にわいてもそれらの傾向を示す報告 ${ }^{26)}$ がみられる.

Glibenclamide 及び Tolbutamide は共に SU 剂であり, 前述した如く glibenclamide も tolbutamide と同様の作用をもつと考えられる.しかし glibenclamide 前投与時には, 正常者群, 及び軽症糖尿病者群 とも GTT 時より有意に I.I が上昇し, 中等症糖尿病者でもそのI.I が上昇する傾向がみられたが, tolbutamide 前投与時では, 正常者群でのみ I.I の上昇をみ, 糖尿病者群では, その上昇が認められなかつ た. この糖尿病者群の両凨間の作異は, その薬剤のもつ本来の作用の強弱 ${ }^{19}$ そよるもので, tolbutamide で はその作用が弱いため, 膵 $\beta$-細胞の機能不全の強い糖尿病者では, I.I の増加がみられなかつたものと考元 られる. 葛谷 ${ }^{27}$ らは tolbutamide を静眽的内に前投与した場合にはブドウ糖静脈内注入後の早期の insulin 反応が糖尿病者でも增加する傾向を認めている.

てれらの事より SU 剤特に glibenclamide は糖尿病治療に食前投与が適すると推測される。

\section{結 語}

Sulfonylurea 剤 (glibenclamide 及び tolbutamide) の血糖降下作用及び insulin 分泌動態を検討した.

1) 糖尿病者の insulin 分泌はブドウ糖のみならず, sulfonylurea 剤である tolbutamide による刺激に 対してもその反応の速効性を欠く.

2 ) 最近開発された glibenclamide は従来のSU 剤である tolbutamide と質的に同一の作用を有する.

3 ) Glibenclamide 及び tolbutamide はそれらを前投与するととにより,ブドウ糖負荷後の早期の insulin 分泌が増強され，膵 $\beta$-細胞のブドウ糖に対する感受性を高めるものと考元られる。

4) SU 剂特に glibenclamide の食前投与は糖尿病の治療に適すると推測される.

本論文の要旨は, 第44回日本内分泌学会総会及び第19回日本内分泌学会西部々会総会にて発表した.

稿を終るにあたり, 御懇切な御指導, 御校閲を戴いた恩師吉田秀雄教授に深甚なる謝意を表します。また 御協力戴いた服部宏博士に深謝いたします。

\section{文献}

1) Janbon, M., J. Chaptal, A. Vedel \& J. Schaap : Montpellier méd, 21-22 : 441, (1942).

Loubatieres, A. : Ann. N.Y. Acad. Sci., 71 : 4, (1957).

3）吉田秀雄：日本内科学会雑誌, 47 :

888, (1958).

4) 吉田秀雄, 他 : 日本内分泌学会雑誌, $34: 705$, (1958).

5) Houssay,

B.A., J.C. Penhos, J. Bowkett \& J. Apelbaum : Ann. N.Y. Acad. Sci., 71 : 12, (1957). 
Mirsky, A., G. Perisutti \& S. Gitelson : Ann. N.Y. Acad. Sci., 71 : 103, (1957).

7) Colwell, A.R., R. Jr \& Metz : Diabetes, 11 : 504, (1962). $\quad$ 8) Creutzfeld, W. \& H. Fintes : Dtsch. Med. Wochr., $81:$ 892, (1956).

9) 吉田秀雄, 他：日本内分泌学会雑誌, 34:758, (1958)

Mirsky, I.A., G. Perisutti \& D. Diengott : Metabolism, 5 : 156, (1956).

11) Rafaelson, O.J. : Metabolism, 8 : 195, (1959).

12) Rafaelson, O.J. \& K. Lundbeck : Metabolism, 8 : 757, (1959).

13) Antoniades, H.N., J.A. Bougas, R. Camerini-Davalos, H.M. Pyle, S.J. Mazurkie, O. Lazano-Castaneda \& A. Marble: The New Engl. J. Med., 2 : 386, (1963). 14) Raptis, S., R.M. Rau, K.E. Schröder, J.D. Faulhaber \& E.F. Pfeiffer : Horm. Metab. Res., Suppl. ad Vol. 1 : 65, (1969). 15) Morgan, G.R. \& A. Lazarow : Diabetes, $12: 115$, (1963). $\quad 16)$ Duncombe, W.G. : Biochem. J., $83: 6$, (1962). 17) Itaya, K. \& M. Ui : Journal of dipid Reseach, $6: 16$, (1965).

Berson, S.A. \& R.S. Yalow : Nature, 184 : 1648, (1959). 19) 吉田秀雄：糖尿病の早期発晃之治療 (1972)，126. 中外医学社 20) Stork, H., E.H. Schmidt, A. Bänder \& W. Pfaff : Arzneim.-Forsch., $19: 1373$ (1969). $\quad 21)$ Mirsky, I.A. : Endocrinology, $73: 63$, (1963). 22) Yalow, R.S., S.M. Glick, J. Roth, \& S.A. Berson : Ann. N.Y. Acad. Sci., 131 : 357, (1965). $\quad$ 23) Yalow, R.S. \& S.A. Berson : J. Clin. Invest. $39: 157$, (1960).

24) Seltzer, H.S., E.W. Allen, Jr Herron \& M.T. Brennen : J. Clin. Invest., $46: 323$ (1967). 25) 唐崎健吉, 七里元亮, 繁田幸男, 大歳 誠 : 糖尿病, $15:$ 104, (1972). 26) Landau, B.R., J.R. Leonards, J.W. Graig, G.R. Shephardson, T. Moriwaki \& M. Miller : Metabolism, $10: 464$, (1961). 27）葛谷英嗣, 他：日本内分泌学会雑 誌, 第20回日本内分泌学会西部々会総会講演抄録 $49: 965$, (1973). 